\title{
INVESTIGATION OF THE METAL CONTENT IN THE SEDIMENT OF OSKARSHAMNS HARBOUR
}

\author{
Ola Lindstrand, \\ VBB VIAK, Sweden \\ Tommy Hammar, \\ Kalmar County Administration, Sweden \\ Jan Sandberg \\ Oskarshamn Municipality, Sweden
}

\begin{abstract}
In the period 1995 to 1998 have several investigations been performed in regard to the metal content in the sediment of Oskarshamns harbour and the connected leakage to the Kalmar sund and the Baltic Sea. The investigations suggest that a total of approximately $600.000 \mathrm{~m}^{3}$ of the sediment is contaminated and in need of remediation. The contamination is dominated by $1.000 \mathrm{~kg}$ of cadmium, $200.000 \mathrm{~kg}$ of copper, $100.000 \mathrm{~kg}$ of lead and $400.000 \mathrm{~kg}$ of zinc. The studies also show that the on-going transport of metals out from the harbour is not connected with the modern input. The yearly transport from the harbour is calculated to be $100 \mathrm{~kg} \mathrm{Cd}, 7.000 \mathrm{~kg} \mathrm{Cu}, 3.000 \mathrm{~kg} \mathrm{Pd}$ and $10.500 \mathrm{~kg} \mathrm{Zn}$.
\end{abstract}

\section{INTRODUCTION}

Oskarshamn city, situated on the east coast of Sweden, $70 \mathrm{~km}$ north Kalmar have since its establishment 1856 a long industrial history of nearly 200 year. Several of the industries have resulted in a severe impact on the environment due to a large accumulation of heavy metals in the sediment of Oskarshamns harbour. 5 larger pollution sources have been identified as follows;

- Ship yards, especially Oskarshamns Varv, during the period of 1860 to 1960.

- Copper industry (Kopparverket) during the period of 1918 to 1969.

- Earlier and continuous production of accumulators at the SAFT NIFE factory, earlier known as Jungnerverken.

- Earlier and continuous stock piling of petroleum products at the large oil depot.

- Recharge of treated, and earlier untreated, sewage water from the city waste water treatment plant. 


\section{SEDIMENT SAMPLING}

In the inner part of the Oskarshamns harbour have a total number of 40 sediment profiles been taken during the field work in 1996. The profiles have been divided and 104 samples have been analysed in laboratory in regard to mainly the content of heavy metals.

The profiles have most of them a minimum depth of 0,6 meter, which is deeper then earlier investigations in the area (normally only 0,05 meter).

\section{SUMMARY OF RESULTS}

The results indicate that the sediment is contaminated by heavy metals within a total area of $1.185 .000 \mathrm{~m}^{2}$, when indicative levels is used recommended by the Swedish Environmental Protection Agency (very high respectively high).

The contaminated sediment have a depth of $0,2 \mathrm{~m}$ to more then $0,6-0,8 \mathrm{~m}$. The total volume of the contaminated sediment in the investigated area is estimated to be approximately 450.000 $\mathrm{m}^{3}$. It is however seen as likely that, when contaminated sediment is included from deeper areas and from the outer part of the harbour, the total contaminated volume is more then $600.000 \mathrm{~m}^{3}$.

With the use of observed mean values and the above volume are the following amounts calculated for some of the metals;

- Cadmium mean value, $5 \mathrm{mg} / \mathrm{kg}$ dry weight

- Copper mean value, $1.300 \mathrm{mg} / \mathrm{kg}$ weight $1.000 \mathrm{~kg}$

- Lead mean value, $630 \mathrm{mg} / \mathrm{kg}$ dry weight $200.000 \mathrm{~kg}$

- Zinc mean value, $2.500 \mathrm{mg} / \mathrm{kg}$ dry weight $100.000 \mathrm{~kg}$ $400.000 \mathrm{~kg}$

\section{LEAKAGE STUDY}

In the period 1997 to 1998 the investigation have continued with two studies of the today transport of heavy metals into the harbour area respectively the transport out from the harbour.

\section{Transport out from the harbour}

The transport was determined by the mean of sampling of both water and sediment, the latter in sediment traps in the harbour itself and with some distance from the entrance to the harbour. The sampling was combined by modelling of the stream-flow in the harbour during different periods (Phoenics-model, modelled by SMHI). 
The study showed that a large amount of the metals found in the sediment is transported out from the harbour to the Kalmar sund and Baltic Sea. The results are summarised in the table below as transport in $\mathrm{kg} / \mathrm{year}$.

They are in the table also compared with similar figures from the River Emån. The river Emån is a river where several remediation project have been executed, is on-going or is planned lake Järnsjön and Jungnerholmarna as two example.

\begin{tabular}{|l|l|l|}
\hline Metal & $\begin{array}{l}\text { Calculated yearly transport out from } \\
\text { the Oskarshamns harbour }\end{array}$ & $\begin{array}{l}\text { Calculated yearly transport from the river } \\
\text { Emån to the Kalmar sund }\end{array}$ \\
\hline $\mathrm{Cd}$ & $100 \mathrm{~kg}$ & $50 \mathrm{~kg}$ \\
\hline $\mathrm{Cu}$ & $7.000 \mathrm{~kg}$ & $2.200 \mathrm{~kg}$ \\
\hline $\mathrm{Pb}$ & $3.000 \mathrm{~kg}$ & $200 \mathrm{~kg}$ \\
\hline $\mathrm{Zn}$ & $10.500 \mathrm{~kg}$ & $3.100 \mathrm{~kg}$ \\
\hline
\end{tabular}

\section{Transport into the harbour}

The studied sources which may have an impact in regard to metal transport have been surface water (Döderhultsbäcken), groundwater and the city WWTP. The results are summarised in the table below as transport in $\mathrm{kg} / \mathrm{year}$;

\begin{tabular}{|l|l|l|l|l|}
\hline Metal & $\begin{array}{l}\text { Surface water } \\
\text { (Döderhultsbäcken) }\end{array}$ & Groundwater & $\begin{array}{l}\text { Treated waste } \\
\text { water }\end{array}$ & Total transport \\
\hline $\mathrm{Cd}$ & $0,4 \mathrm{~kg}$ & $1,5 \mathrm{~kg}$ & $0,6 \mathrm{~kg}$ & $2,5 \mathrm{~kg}$ \\
\hline $\mathrm{Cu}$ & $10 \mathrm{~kg}$ & $6,6 \mathrm{~kg}$ & $56 \mathrm{~kg}$ & $72,6 \mathrm{~kg}$ \\
\hline $\mathrm{Pb}$ & $1,5 \mathrm{~kg}$ & $0,4 \mathrm{~kg}$ & $3,7 \mathrm{~kg}$ & $5,6 \mathrm{~kg}$ \\
\hline $\mathrm{Zn}$ & $48 \mathrm{~kg}$ & $28 \mathrm{~kg}$ & $114 \mathrm{~kg}$ & $190 \mathrm{~kg}$ \\
\hline
\end{tabular}

\section{Conclusion}

It is clearly indicated that the today transport of the metals out of the harbour is very large, even when the transport is compared with another known large metal source (Emån). It is also clearly indicated that the today transport of the metals into the harbour area is relatively low and definitively much smaller then the transport out from the harbour.

Hence, the large impact visible in the Kalmar sund from other studies, can clearly be said to be connected to the contaminated sediments already deposited in the Oskarshamn harbour.

It can also be argued that the transport from harbour should be more studied. One reason is that this study suggest that the main reason for the sediment to leak metals is re-suspension of the sediment due to the harbour activity itself (i.e. ships, ferries etc.). Another reason is that the biological impact of the transport is not fully known. 